\title{
TELENCEPHALIC ENKEPHALINERGIC SYSTEMS IN THE RAT BRAIN $^{1}$
}

\author{
HENRY KHACHATURIAN, ${ }^{2}$ MICHAEL E. LEWIS, VOLKER HOLLT, ${ }^{*}$ AND STANLEY J. WATSON \\ Mental Health Research Institute, University of Michigan, Ann Arbor, Michigan 48109 and * Max Planck Institute for \\ Psychiatry, Munich, West Germany
}

Received May 20, 1982; Revised August 9, 1982; Accepted October 8, 1982

\begin{abstract}
The comparative distribution of Leu-enkephalin and an enkephalin precursor fragment, BAM$22 \mathrm{P}$, was studied in the rat telencephalon using immunocytochemical procedures. Although the enkephalins have previously been localized to telencephalic neurons, the use of high doses of colchicine in the present study has permitted the visualization of widespread enkephalin-containing systems in cortical-limbic regions. Rats were treated intraventricularly with colchicine (300 to 400 $\mu \mathrm{g})$ to enhance the visualization of neuronal perikarya. Leu-enkephalin immunoreactivity was noted in perikarya as well as processes of neurons in many telencephalic regions including the olfactory bulb, parolfactory areas, olfactory tubercle, basal ganglia, nucleus accumbens, septal nuclei, amygdala, hippocampal formation, and several paleocortical regions such as the piriform, entorhinal, and cingulate cortex, as well as regions of the frontal, parietal, and occipital neocortex. In the majority of regions investigated, analysis of sections adjacent to those processed for Leu-enkephalin histochemistry showed BAM-22P immunoreactivity to be localized to perikarya and processes in the same region. These results suggest that brain enkephalin-positive neurons may possess mechanisms for enkephalin biosynthesis similar to those found in adrenal medullary enkephalin cells.
\end{abstract}

The enkephalins (Hughes et al., 1975) are opioid peptides with known opiate agonist activity (for review, see Snyder, 1980) and are present in many brain regions in varying concentrations (Miller et al., 1978). These peptides, methionine- and leucine-enkephalin (Met- and Leu-enkephalin), form neuronal systems which are anatomically and biosynthetically distinct from the opioid $\beta$-endorphin neuronal systems (Mains et al., 1977; Roberts and Herbert, 1977; Bloom et al., 1978; Watson et al., 1978; Nakanishi et al., 1979). Also, some evidence exists for the anatomical separateness of Leu- versus Met-enkephalin (Larsson et al., 1979). Biosynthetic mechanisms for the enkephalins have been studied extensively in adrenal medulla (Kimura et al., 1980; Comb et al., 1982; Gubler et al., 1982; Noda et al., 1982). The enkephalin precursor has a calculated $M_{\mathrm{r}}$ of 29,786 and contains the amino acid sequences of Met-enkephalin (6 copies) and Leu-enkephalin (1 copy).

${ }^{1}$ This work was supported by National Institute of Drug Abuse (NIDA) Grant DA02265 and NIDA Center Grant DA00154 to S. J. W. National Institute of Mental Health Training Grant MH15794 to H. K., a John G. Searle Clinical Pharmacology Fellowship to M. E. L., and Deutsche Forschungsgemeinschaft to V. II. We wish to thank M. van der Veen, G. Baldrighi, S. Burke, and K. Shiomi for expert assistance, and $\mathrm{M}$. Ritchie for manuscript preparation.

${ }^{2}$ To whom correspondence should be addressed.
Enkephalin-containing neurons have a wide distribution throughout the neuraxis. They are present in brain regions implicated in autonomic and neuroendocrine regulation as well as in diverse behavioral functions. Radioimmunoassay measurements have shown high concentrations of enkephalin in the striatum, followed by the diencephalon, brainstem, and various cortical-limbic regions (Rossier et al., 1977; Yang et al., 1977; Kobayashi et al., 1978; Miller et al., 1978). Also, numerous immunocytochemical studies have extended our knowledge of the specific sites of enkephalin localization in the brain (Elde et al., 1976; Hokfelt et al., 1977a, b, 1979; Watson et al., 1977a; Simantov et al., 1977; Sar et al., 1978; Uhl et al., 1978, 1979; Rossier et al., 1979; Jacobowitz et al., 1979; Micevych and Elde, 1980; Pickel et al., 1980; Wamsley et al., 1980; Finley et al., 1981).

Because there are relatively low concentrations of enkephalins in some brain areas, such as the cerebral cortex and many parts of the limbic system, immunocytochemical studies have not resulted in a consistent picture of enkephalin cell and fiber localization in these areas. For example, without colchicine pretreatment, the cerebral cortex shows no immunoreactive enkephalin cells and fibers (Elde et al., 1976; Watson et al., 1977a) despite the presence of immunoassayable material (Yang et al., 1977; Miller et al., 1978). Subsequent studies on rats either 
with or without colchicine pretreatment have succeeded in visualizing a few enkephalin-positive terminals and fibers in some cortical areas (Sar et al., 1978; Wamsley et al., 1980) and enkephalin-positive cells appearing sporadically in layers II to VI in neocortex (Finley et al., 1981) and more densely in layers II to III of the entorhinal cortex (Gall et al., 1981). However, because of the problem of immunocytochemical staining sensitivity, these observations may not account for the full extent of cortical-limbic enkephalin pathways. In the present study, utilization of very high doses of colchicine as pretreatment has permitted the visualization of extensive systems of cortical-limbic enkephalin pathways. Furthermore, in order to provide evidence regarding the presence of the enkephalin precursor processing system in cortical-limbic neuronal systems, we also determined the distribution of an enkephalin precursor fragment, BAM-22P, from bovine adrenal medulla (Mizuno et al., 1980)) (Fig. 1).

\section{Materials and Methods}

Adult male Sprague-Dawley rats were treated with varying amounts of colchicine $(50,100,200,300,350$, and $400 \mu \mathrm{g})$ injected as a bolus $(10 \mu \mathrm{l})$ into the right lateral ventricle to enhance cell body visualization. These rats were sacrificed at 24 or $48 \mathrm{hr}$ after treatment. Each animal was anesthetized with sodium pentobarbital (50 $\mathrm{mg} / \mathrm{ml}$, i.p.), the chest cavity was exposed, and the cardiovascular system was flushed with $50 \mathrm{ml}$ of ice-cold normal saline. For fixation, ice-cold $4 \%$ neutral buffered formaldehyde was systemically perfused at $140 \mathrm{~mm} \mathrm{Hg}$ for $30 \mathrm{~min}$. The brain was removed and either postfixed in the same fixative for $30 \mathrm{~min}$ and immersed in $15 \%$ sucrose, or was directly immersed in $15 \%$ sucrose and then stored overnight at $4^{\circ} \mathrm{C}$. Freezing was achieved by the immersion of the brains in $-40^{\circ} \mathrm{C}$ isopentane for 30 to $40 \mathrm{sec}$ and then embedding in powdered dry ice. Frontal, parasagittal, and horizontal sections of $20 \mu \mathrm{m}$ thickness were obtained using a cryostat $\left(-20^{\circ} \mathrm{C}\right)$ and were stored at $-70^{\circ} \mathrm{C}$.

Immunocytochemical staining with primary antisera against Leu-enkephalin (Watson et al., 1977b) and BAM22P (antiserum "Tristan;" Hollt et al., 1981) was carried out as follows. Sections were air-dried and incubated $\left(37^{\circ} \mathrm{C}\right)$ with normal goat serum (NGS) (Grand Island Biological Co.) at $1 / 30$ dilution for 5 to $10 \mathrm{~min}$ and then with the primary rabbit antiserum (Table I) for $1 \mathrm{hr}$ at $37^{\circ} \mathrm{C}$, and overnight (approximately $24 \mathrm{hr}$ ) at $4^{\circ} \mathrm{C}$. On some sections, for control purposes, each antiserum was pre-adsorbed with 25 to $50 \mu \mathrm{M}$ peptide (Leu-enkephalin, Met-enkephalin, BAM-22P, or dynorphin-17) in a crossblocking paradigm to ensure antibody specificity. The

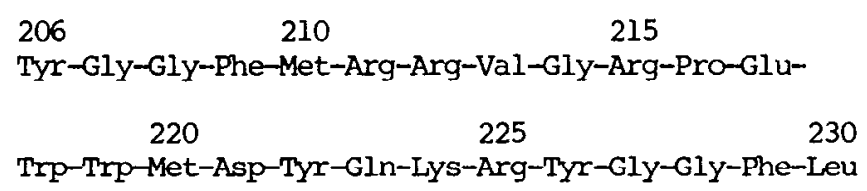

Figure 1. Amino acid sequence of bovine adrenal medullary enkephalin precursor fragment, peptide $\mathrm{E}$, containing the sequences of BAM-22P (residues 206 to 227), Met-enkephalin (residues 206 to 210), and Leu-enkephalin (residues 226 to 230), according to Noda et al. (1982).
TABLE I

List of antisera

\begin{tabular}{|c|c|c|c|}
\hline Antibody & Source & Specificity & $\begin{array}{c}\text { Key Cross-reactiv- } \\
\text { ities }\end{array}$ \\
\hline $\begin{array}{l}\text { Leu-enkephalin } \\
\text { (affinity) }\end{array}$ & $\begin{array}{c}\text { Watson and } \\
\text { Akil (1981) }\end{array}$ & $\begin{array}{l}\mathrm{COOH}- \\
\text { terminus }\end{array}$ & $\begin{array}{c}<6 \% \text { with Met- } \\
\text { enkephalin }\end{array}$ \\
\hline $\begin{array}{l}\text { BAM-22P } \\
\text { (enkephalin } \\
\text { precursor } \\
\text { fragment) }\end{array}$ & $\begin{array}{c}\text { Hollt et al. } \\
(1981)\end{array}$ & $\begin{array}{l}\mathrm{COOH}- \\
\text { terminus }\end{array}$ & $\begin{array}{l}\text { Neither enkeph- } \\
\text { alin nor BAM- } \\
\text { I2P }\end{array}$ \\
\hline
\end{tabular}

next day, the sections were thoroughly washed in $0.02 \mathrm{M}$ phosphate-buffered saline (PBS) and incubated $\left(37^{\circ} \mathrm{C}\right)$ with NGS (5 to $10 \mathrm{~min}$ ), and then with goat-anti-rabbit serum (Sternberger-Meyer) at 1/100 dilution for $30 \mathrm{~min}$ at $37^{\circ} \mathrm{C}$, and overnight (approximately $24 \mathrm{hr}$ ) at $4^{\circ} \mathrm{C}$. On the 3 rd day, the sections were washed in PBS and incubated $\left(37^{\circ} \mathrm{C}\right)$ with NGS, then with rabbit anti-horseradish peroxidase (HRP) serum at $1 / 200$ dilution for $40 \mathrm{~min}$ at $37^{\circ} \mathrm{C}$. These were then washed in PBS and subsequently were incubated with HRP enzyme (Sigma, type VI), $4 \mu \mathrm{g} / \mathrm{ml}$, for $40 \mathrm{~min}$ at $37^{\circ} \mathrm{C}$. Again, the sections were washed in PBS and were immersed in a solution of 0.125 $\mathrm{mg} / \mathrm{ml}$ of diaminobenzidine (Sigma) and $0.03 \% \mathrm{H}_{2} \mathrm{O}_{2}$, for $15 \mathrm{~min}$. Then they were washed in distilled water, briefly osmicated $\left(2 \% \mathrm{OsO}_{4}\right)$, rewashed, dehydrated through increasing concentrations of ethanols and xylenes, and mounted with Permount. Observations and photography were made using a Leitz Orthoplan microscope.

The Leu-enkephalin antiserum was purified in an affinity chromatography column with cyanogen bromideactivated Sepharose-4B (March et al., 1974) onto which Leu-enkephalin was linked in order to purify IgG molecules with significant affinity toward the antigen. This approach has the added benefit of concentrating specific antibodies while reducing the nonspecific antibody content. Removal of the nonspecific IgG molecules reduces nonspecific binding to tissue and greatly reduces background. Thus the visible signal is greatly enhanced (see Watson and Akil, 1981, for a review).

\section{Results}

Immunoreactive Leu-enkephalin perikarya and processes are widely distributed throughout telencephalic cortical-limbic structures. These include: olfactory bulb, tuberculum olfactorium, piriform cortex, nucleus accumbens, diagonal band of Broca, septal nuclei, nucleus caudate-putamen, globus pallidus, several amygdaloid nuclei, entorhinal cortex, hippocampal formation, cingulate cortex, and several neocortical areas (Fig. 2, $A$ to $E$ ). Most of these areas also contain BAM-22P-immunoreactive neurons in anatomical position similar to that of Leu-enkephalin neurons (Figs. 4 and 6). In cortex, Leuenkephalin immunoreactivity often appeared more concentrated in the initial segment of the axon than in the perikaryon (Fig. $6 \mathrm{C}$ ), whereas BAM-22P immunoreactivity appeared mainly in the perikaryon (Fig. 6D). Furthermore, Leu-enkephalin and BAM-22P completely blocked the immunoreactive signal obtained by Leu-enkephalin and BAM-22P antisera, respectively. Blocking was selective since Met- and Leu-enkephalin did not block the signal obtained with BAM-22P antiserum, nor 

(A)
(B)
(C)

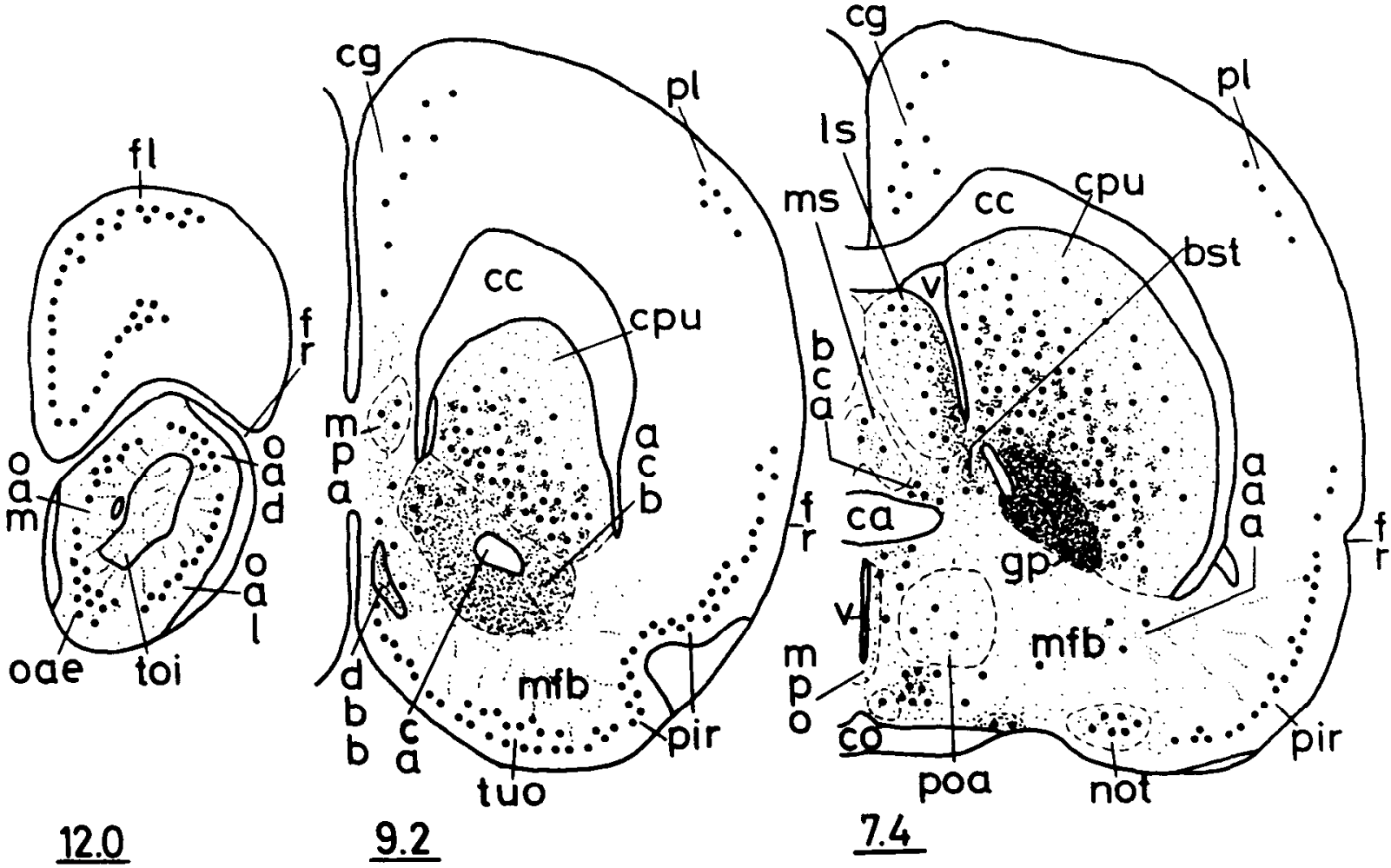

(D)

(E)
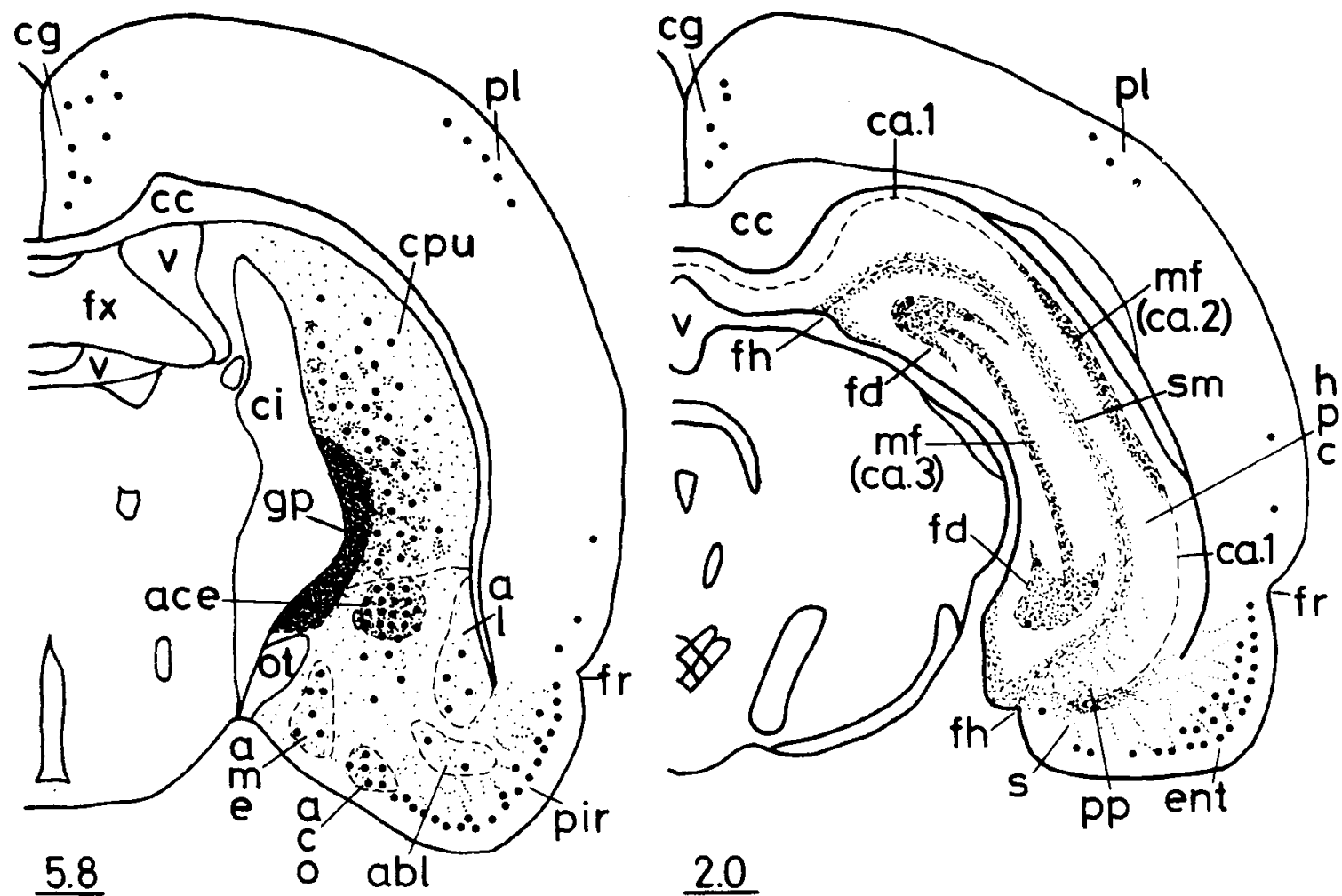

Figure 2. These schematic frontal sections show the distribution of Leu-enkephalin perikarya (solid circles) and processes or terminals (dots) in five selected levels ( $A$ through $E$ ) through the rat telencephalon. Diencephalic and mesencephalic enkephal- 
did BAM-22P block the immunoreactivity obtained using anti-Leu-enkephalin serum. Furthermore, dynorphin-17 did not block the immunoreactive signal obtained using either leu-enkephalin or BAM-22P antisera.

In the olfactory bulb, many small immunoreactive perikarya form a ring-like cluster of cells several layers thick around the intermediate olfactory tract into which immunoreactive processes project. The perikarya are distributed within the external, lateral, dorsal, and medial parts of the anterior olfactory nucleus (Figs. $2 A$ and $3 A$ ). Fine varicose immunoreactive processes also occur in discrete clusters in the glomerular layer of the olfactory bulb (Fig. $3 D$ ). More caudally, small perikarya can also be seen in the tuberculum olfactorium and adjoining piriform cortex as a continuous band of cells that stretches laterally and dorsally to the rhinal fissure (Figs. $2 B$ and $3 C$ ). Furthermore, in the tuberculum olfactorium, perikarya are seen in both superficial and deep cortical layers, whereas in the piriform cortex most perikarya occur in layer II. Very few perikarya exist dorsal to the rhinal fissure and, when encountered, are faintly immunoreactive. The nucleus accumbens, dorsal to the tuberculum olfactorium, also contains dense immunoreactive processes and terminals and some perikarya in regions medial to the anterior commissure (Fig. $2 B$ ). Continuous with perikarya in the tuberculum olfactorium are scattered immunoreactive perikarya as well as processes in the region of the diagonal band of Broca and the medial parolfactory area (Fig. $2 B$ ).

More caudally, in the septal region, immunoreactive perikarya and processes are situated in the lateral and, to a lesser extent, in the medial septum (Figs. $2 C$ and 5). In the lateral septum, a particularly dense cluster of immunoreactive terminals is present in the ventrolateral region (Fig. $5 B$ ). The nucleus caudate-putamen contains small enkephalin-positive perikarya and fine, patchy varicose processes (Figs. 2, $B$ to $D$, and $4 A$ ). The majority of these perikarya are situated adjacent to the globus pallidus. A very dense network of fibers and fine terminal processes outline the globus pallidus so heavily that this area is clearly distinguishable at low magnifications (Figs. $2 C$ and $D$, and $4 A$ ).

In the piriform cortex, many small enkephalin-positive perikarya outline the amygdaloid complex of nuclei (Figs. $2 D$ and 6). At this level, the majority of cortical cells are present in layer II. Medial to the piriform cortex, the cortical amygdaloid nucleus (periamygdaloid cortex) is densely populated with immunoreactive cells (Fig. $2 D$ ).
In the amygdala, perikarya are scattered in several nuclei, the most prominent of which is the central nucleus, which appears to be densely populated with immunoreactive cells and fibers (Figs. $2 D$ and $7 A$ ). Some perikarya and fibers also exist in anterior, medial, lateral, basal, and intercalated amygdaloid nuclei (Fig. $7 B$ ).

In the entorhinal cortex, immunoreactive Leu-enkephalinergic perikarya are situated in both lateral and medial cortical areas. In the lateral entorhinal cortex, these cells appear in two bands in layers II and III and end dorsally at or just beyond the rhinal fissure in the perirhinal area (Figs. $2 E$, and $8, A$ and $B$ ). From these entorhinal cortical cells, immunoreactive processes appear to project through the subiculum and into the hippocampal formation (Figs. $2 E$ and $8, A$ and $C$ ). In the hippocampal formation, fine immunoreactive fibers and terminals are situated within the stratum moleculare of the dentate gyrus (containing the dendrites of granule cells). A few scattered immunoreactive perikarya are also seen in the stratum granulosum of the dentate gyrus (Figs. $2 E$ and $8 A$ ). Fine varicose immunoreactive processes are localed on the apical side of the stratum pyramidale (areas CA2 and CA3) of the hippocampus proper, which appear to correspond to the mossy fiber projections of granule cells (Figs. $2 E$ and $8 A$ ).

In the cingulate cortex, small immunoreactive perikarya are seen to be widely scattered throughout its rostral-caudal extent in layers II to VI (Fig. 2, $B$ to $E$ ). In neocortex, immunoreactive perikarya were observed in the frontal, parietal, and occipital cortex, where they appear to be distributed primarily in layer II and to a lesser extent in deeper layers (Figs. 2, $A$ to $E$, and 9).

\section{Discussion}

In this study, colchicine-treated rates were used to investigate the distribution of Leu-enkephalin neurons in telencephalic cortical-limbic structures. Colchicine treatment enhanced the visualization of perikarya presumably by inhibiting microtubule formation and thus axonal transport of synthesized material (Norstrom et al, 1971). Colchicine treatment also enhanced the visualization of the dendrites, initial segments of axons, and axonal projection pathways. The best results were obtained with 300 to $400 \mu \mathrm{g}$ of colchicine administered 24 or $48 \mathrm{hr}$ antemortem; these treatments allowed the visualization in cortical-limbic areas of the smallest enkephalinergic perikarya which were not detectable in the absence or

inergic systems are not included. The number in the lower left-hand corner of each drawing indicates the distance of that section from the vertical zero plane (de Groot, 1959; Pellegrino et al., 1979). aaa, anterior amygdaloid area; $a b l$, basal amygdaloid nucleus; $a c b$, nucleus accumbens, lateral parolfactory area; ace, central amygdaloid nucleus; aco, cortical amygdaloid nucleus; $a l$, lateral amygdaloid nucleus; ame, medial amygdaloid nucleus; $b c a$, bed nucleus of the anterior commissure; bst, bed nucleus of the stria terminalis; $c a$, anterior commissure; ca.1, hippocampal field CA1; ca.2, hippocampal field CA2; ca.3, hippocampal field CA3; cc, corpus callosum; $c g$, cingulate cortex; $c i$, internal capsule; $c o$, optic chiasm; $c p u$, nucleus caudate-putamen; $d b b$, diagonal band of Broca; ent, entorhinal cortex; $f d$, fascia dentata, dentate gyrus; $f h$, hippocampal fissure; $f l$, frontal cortex; $f r$, rhinal fissure; $f x$, fornix; $g p$, globus pallidus; $h p c$, hippocampus, cornu ammonis; $l s$, lateral septal nucleus; $m f$, mossy fiber projection of hippocampus; $m f b$, medial forebrain bundle; $m p a$, medial parolfactory area; $m p o$, medial preoptic area; $m s$, medial septal nucleus; not, nucleus of the olfactory tract; oad, anterior olfactory nucleus, pars dorsalis; oae, anterior olfactory nucleus, pars externa; oal, anterior olfactory nucleus, pars lateralis; oam, anterior olfactory nucleus, pars medialis; ot, optic tract; pir, piriform cortex; $p l$, parietal cortex; $p o a$, lateral preoptic area; $p p$, perforant pathway of hippocampal formation; $s$, subiculum; sm, stratum moleculare of dentate gyrus; to $i$, intermediate olfactory tract; tuo, olfactory tubercle, tuberculum olfactorium; $v$, ventricle. 

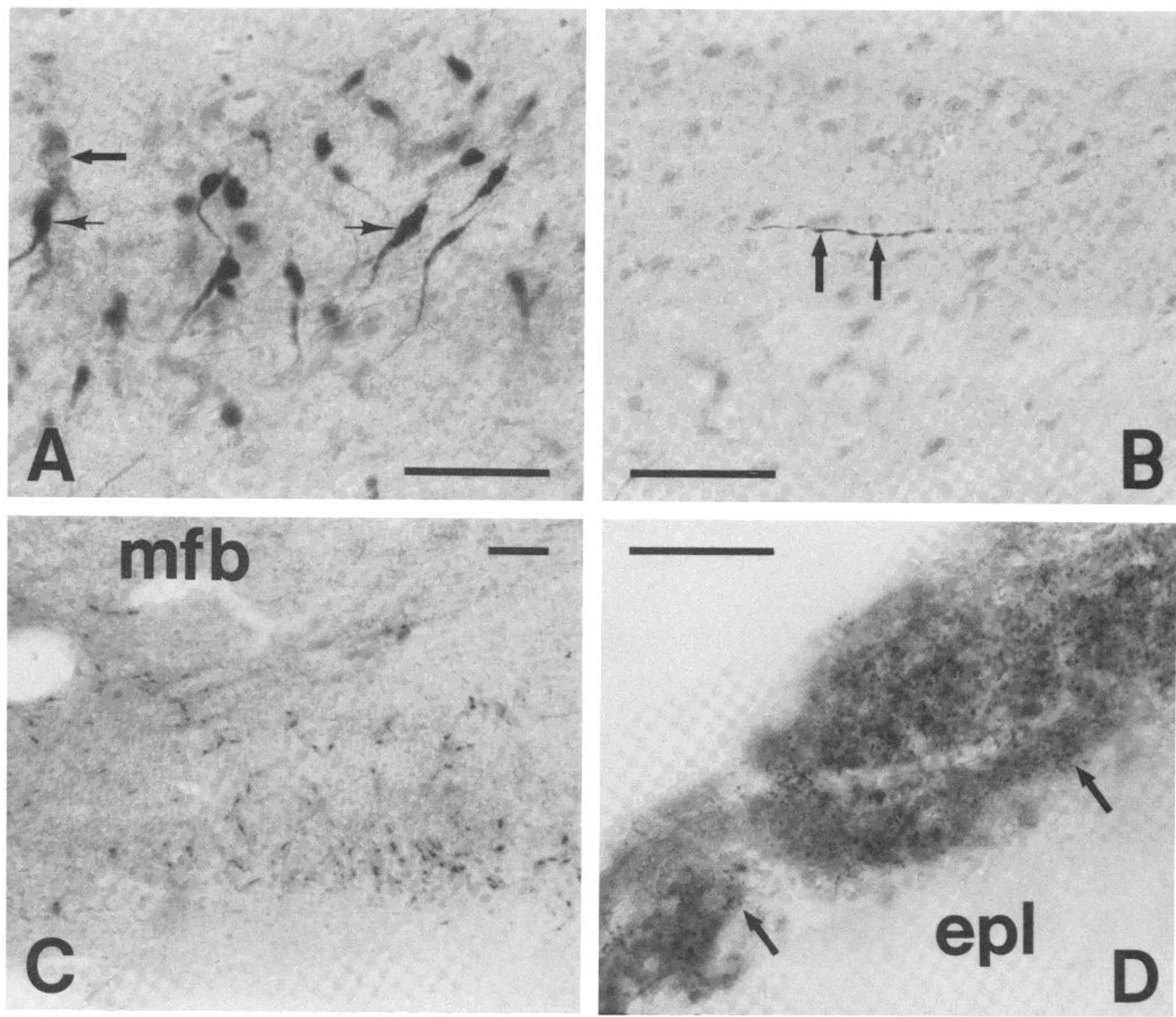

Figure 3. The olfactory system in parasagittal sections. $A$ shows immunoreactive Leu-enkephalin neurons within the medial part of the anterior olfactory nucleus. Note that the small arrows point to initial segments of axons, while the large arrow points to a faintly staining perikaryon. An immunoreactive fiber (arrows) in the intermediate olfactory tract is shown in $B$, and diffuse Leu-enkephalin immunoreactivity in the glomerular layer (arrows) of the olfactory bulb is demonstrated in $D$. $C$ shows immunoreactive neurons in the tuberculum olfactorium. epl, external plexiform layer; $m f b$, medial forebrain bundle. $B a r s=50$ $\mu \mathrm{m}$.

with lower amounts of colchicine. Although there is evidence that direct intracerebral injection of colchicine can result in neuronal damage (Goldschmidt and Steward, 1982), examination of Nissl-stained tissue in the present study did not reveal evidence of neuronal damage outside of the cannula track resulting from intraventricular colchicine administration.

Comparison of the distribution of Leu-enkephalin and an enkephalin-precursor fragment, BAM-22P, showed these two immunoreactivities to be similarly distributed in various telencephalic regions, suggesting substantial similarity between the proenkephalin precursor structure found in adrenal gland (Gubler et al., 1982; Noda et al., 1982 ) and that in rat brain. In most areas studied for Leu-enkephalin, adjacent section analysis showed BAM-
$22 \mathrm{P}$ to be present in neurons of the same region. Whether Leu-enkephalin and BAM-22P immunoreactivity are colocalized within the same neurons is currently being studied. However, in the present study, the thickness of the sections $(20 \mu \mathrm{m})$ precluded co-localization studies, since many Leu-enkephalin-positive neurons are smaller than $20 \mu \mathrm{m}$ in diameter (except for hypothalamic magnocellular and medullary gigantocellular neurons which may contain enkephalin). Appropriate cross-blocking studies showed each antiserum to be specific for its particular peptide. Neither Leu- nor Met-enkephalin blocked the immunoreactivity observed using the BAM22P antiserum. Likewise, BAM-22P did not block the Leu-enkephalin-immunoreactive signal. Finally, neither immunoreactivity was blocked by dynorphin-17. 

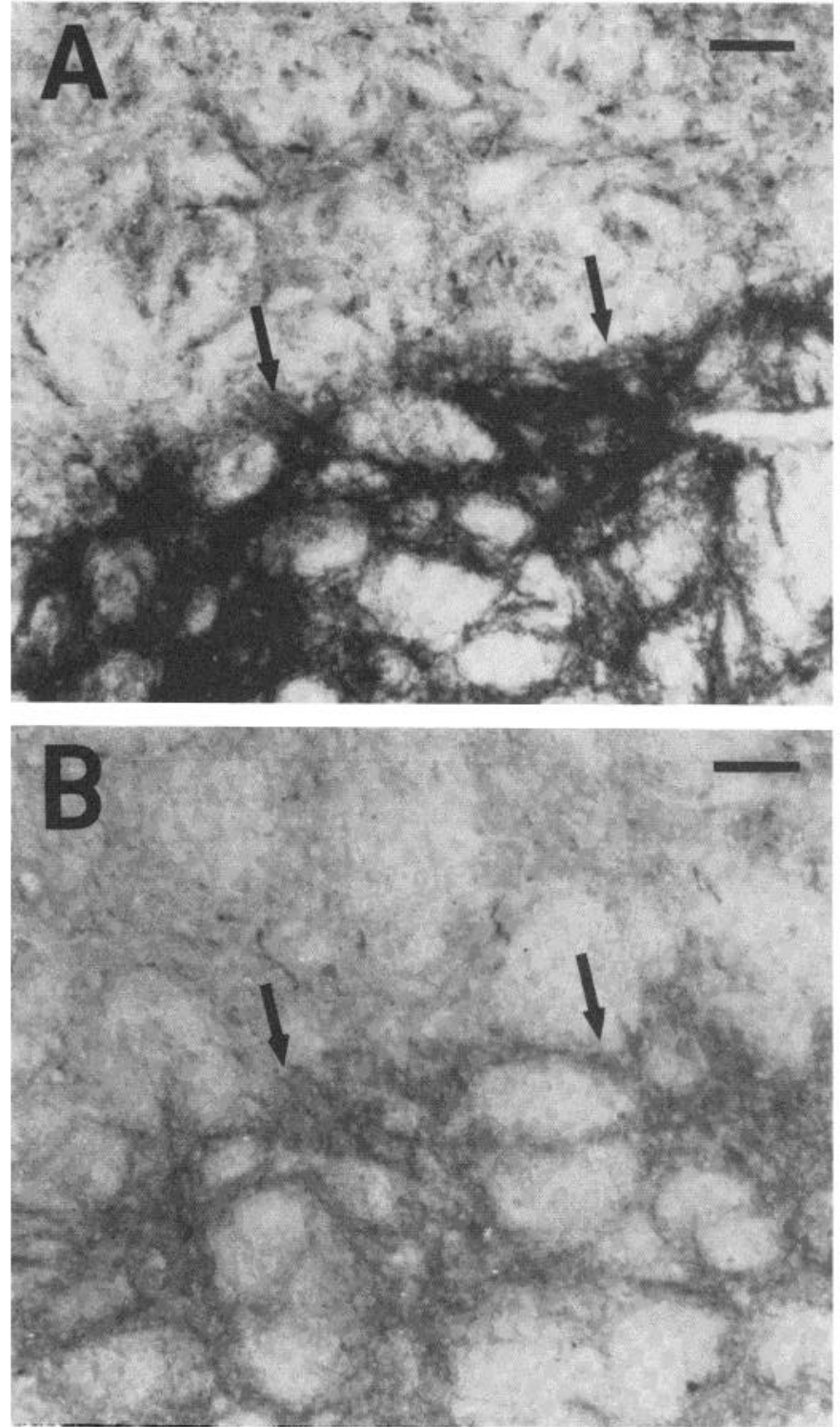

Figure 4. Nucleus caudate-putamen and globus pallidus. $A$ and $B$ are adjacent sections showing Leu-enkephalin $(A)$ and BAM-22P $(B)$ immunoreactivity within the nucleus caudateputamen and globus pallidus (arrows in $A$ and $B$ ). Note the immunoreactive neurons and dense patches of immunoreactive Leu-enkephalin fibers in the nucleus caudate-putamen. Bars $=50 \mu \mathrm{m}$.

The majority of telencephalic Leu-enkephalin-immunoreactive neurons observed in this study are small bipolar or multipolar neurons, although larger enkephalincontaining neurons exist in the hypothalamic magnocellular nuclei (Micevych and Elde, 1980) and the medullary gigantocellular reticular nucleus (Finley et al., 1981). Leuenkephalin perikarya were seen in olfactory bulb nuclei, the tuberculum olfactorium, nucleus accumbens, septal nuclei, nucleus caudate putamen, amygdaloid nuclei, hippocampal formation, and limbic-associated cortical areas including the piriform, periamygdaloid, entorhinal, and cingulate cortex, as well as several neocortical regions.

Most previous studies of enkephalin localization have not described many of the limbic-associated cortical en- kephalin systems (Elde et al., 1976; Hokfelt et al, 1977a; Simantov et al., 1977; Watson et al., 1977a). In subsequent studies utilizing colchicine, relatively few enkephalinpositive fibers and terminals have been visualized in cortical areas (Sar et al., 1978; Wamsley et al., 1980). More recently, Finley et al. (1981) have described several cortical and limbic regions where enkephalin perikarya previously were not reported. These include the olfactory bulb, tuberculum olfactorium, some amygdaloid nuclei, hippocampus, cingulate cortex, and neocortex. In this study, we report additional areas of enkephalin localization, including perikarya situated in several regions of the anterior olfactory nucleus, and in axonal projections within the intermediate olfactory tract, which appear to
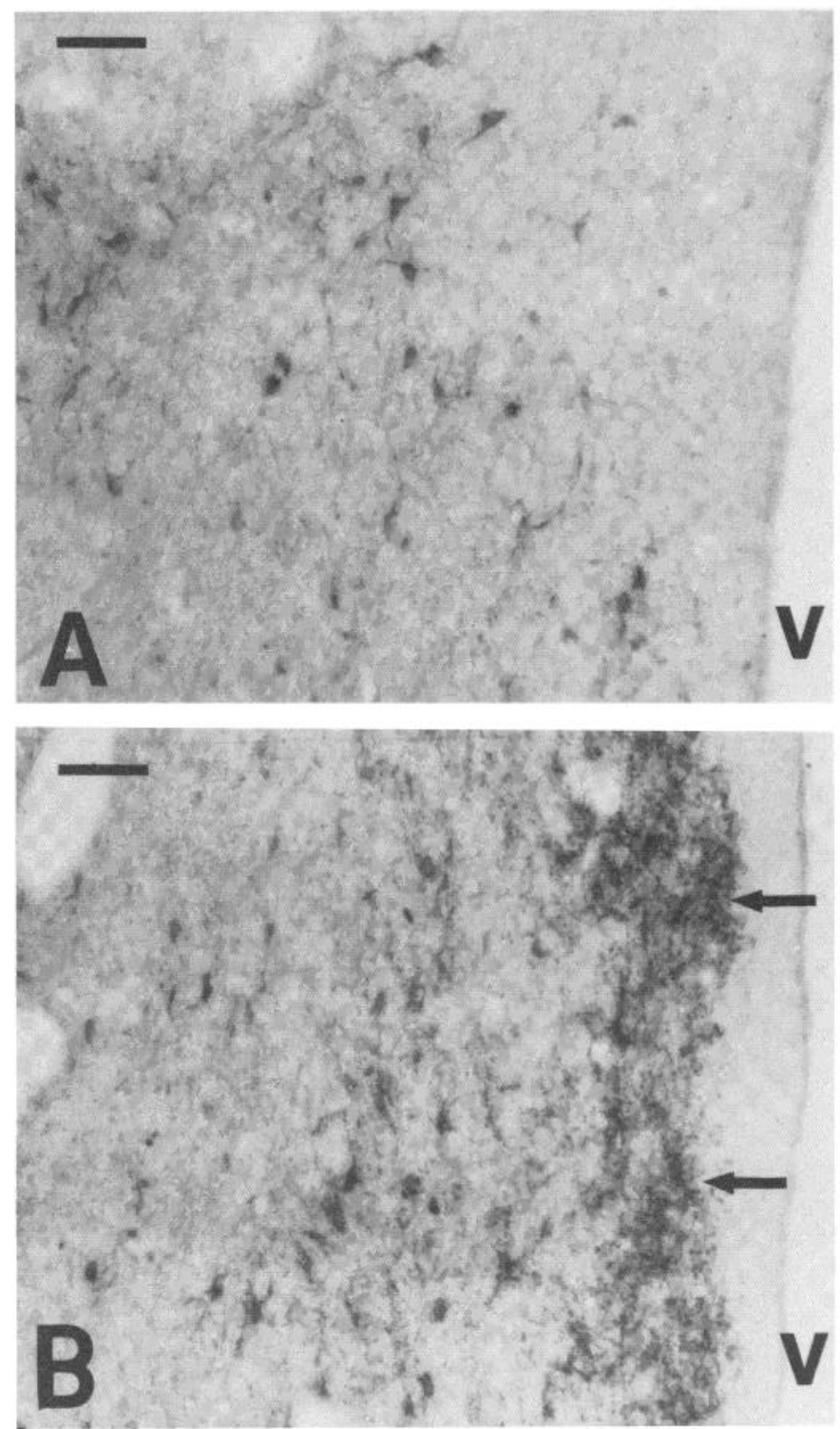

Figure 5. Lateral septum. Frontal sections through the lateral septal nucleus show Leu-enkephalin-positive perikarya within dorsal $(A)$ and ventral $(B)$ aspects of this nucleus. Note the moderately dense immunoreactive network of terminals ( $a r$. rows) in the subependymal region in $B . v$, lateral ventricle. Bars $=50 \mu \mathrm{m}$. 

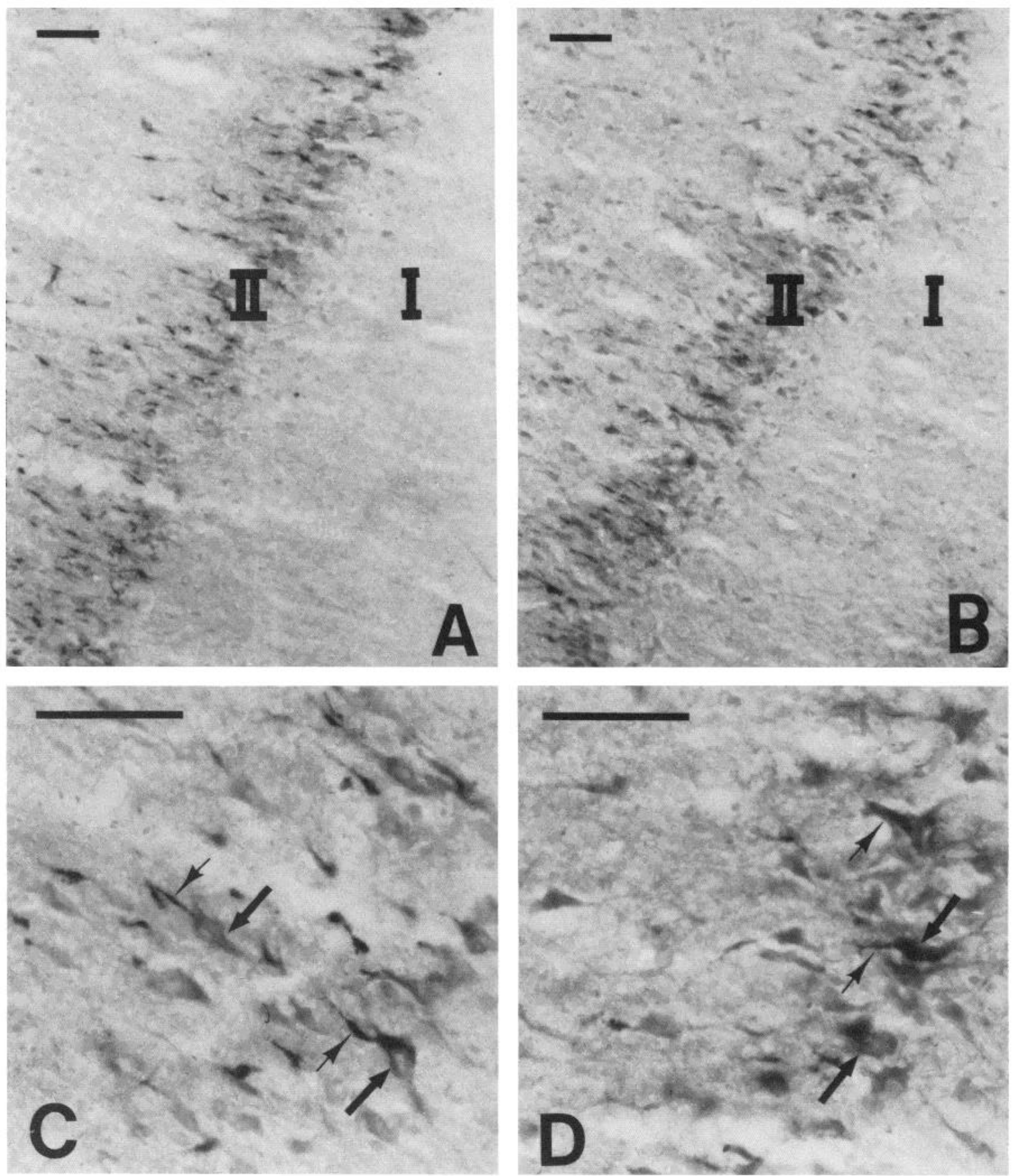

Figure 6. Piriform cortex. These adjacent frontal sections ( $A$ and $B)$ show Leu-enkephalin $(A)$ - and BAM-22P $(B)$ immunoreactive neurons in a similar location in the piriform cortex (mainly in layer $I I$ ). $C$ and $D$ are higher magnifications of $A$ and $B$, respectively, Note that Leu-enkephalin immunoreactivity is often concentrated in the initial segment of the axon (small arrows), whereas BAM-22P immunoreactivity appears preferentially in the perikaryon (large arrows). Bars $=50 \mu \mathrm{m}$.

arise from the latter perikarya. However, we were able to see only occasional immunoreactive periglomerular cells of the bulb as reported (Finley et al., 1981). Furthermore, we have noted a more organized cortical arrangement of the enkephalin perikarya than previously reported. Immunoreactive perikarya were seen in the piriform, periamygdaloid, and entorhinal cortical, and several neocortical regions. Although some of these perikarya are seen in deeper cortical laminae, the majority are present in layer II. A row of small immunoreactive perikarya was observed in the piriform cortex extending laterally to the rhinal fissure, with occasional perikarya seen dorsal to this fissure in the perirhinal area. In the entorhinal cortex, immunoreactive neurons were noted in layers II and III and appeared to project toward the subiculum. Gall et al. (1981) have described in detail the enkephali- 

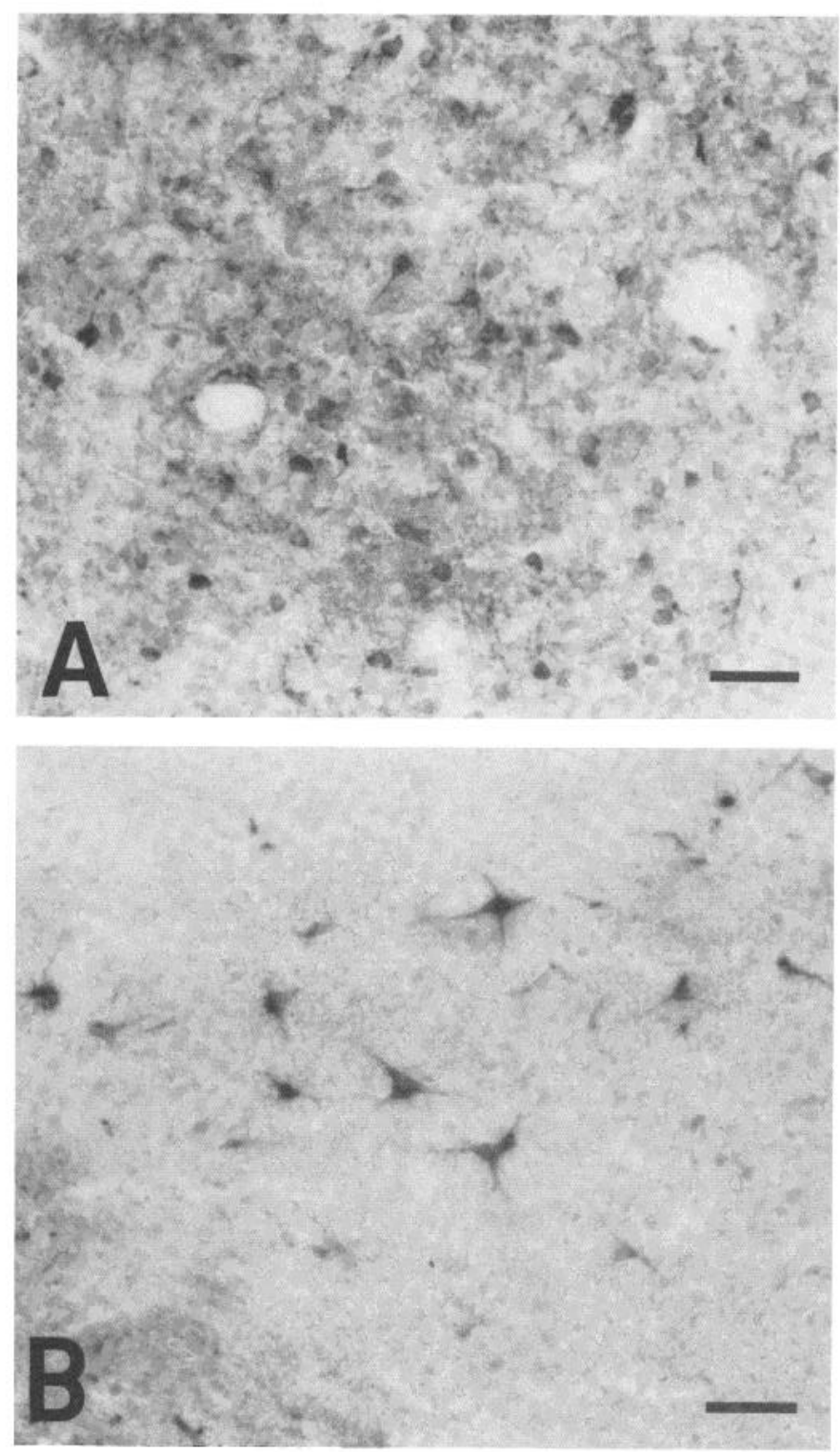

Figure 7. Amygdala. $A$ shows Leu-enkephalin-positive perikarya in the central amygdaloid nucleus. Other amygdaloid nuclei with Leu-enkephalin immunoreactivity include the intercalated amygdaloid nucleus $(B)$. Bars $=50 \mu \mathrm{m}$.

nergic systems of the hippocampal formation. Our results agree with their observations, with the possible exception that we were able to see only occasional immunoreactive perikarya within the stratum granulosum of the dentate gyrus and even fewer in the stratum pyramidale of hippocampal area CA1 or in the subiculum. The enkephalinergic projections to the stratum moleculare of the dentate gyrus appear to originate from perikarya in the entorhinal cortex, reaching their targets via the perforant path. This system appears to correspond to the entorhinal-hippocampal projectional system described using tract tracing methods (Hjorth-Simonsen, 1972; Steward, 1976). The second, intrahippocampal enkephalinergic system, also described by Gall et al. (1981), corresponds to the mossy fiber projection from the granule cells of the dentate gyrus to hippocampal fields CA3 and CA2 (Blackstad et al., 1970; Swanson et al., 1978). No fiber immunoreactivity was noted in field CA1.

In sum, we have noted enkephalin and BAM-22P immunoreactivity in many structures of the limbic system, including olfactory-associated areas, septum, amygdala, hippocampus, and paleocortex. We have also noted widespread enkephalin and BAM-22P immunoreactivity in other limbic-related areas within the diencephalon and mesencephalon, which will be the subject of future reports.

The physiological roles played by the enkephalins and other opioid peptides are still being investigated. The enkephalins have been implicated in such central nervous system regulatory functions as nociception (Belluzzi et al., 1976; Duggan et al., 1976; Leyben et al., 1976), control of respiration and heart rate (Cowan et al., 1976; Florez and Mediavilla, 1977), neuroendocrine control (Lien et al., 1976; Dupont et al., 1977; May et al., 1979a, b), euphoria and drive-reduction reward (Belluzzi and Stein, 1977), memory (Collier et al., 1981), and attention (Davis et al., 1980; Arnsten et al., 1981; Lewis et al., 1981a). Electrophysiological studies with the enkephalins seem to demonstrate an inhibitory role (i.e., depression of firing rates of responsive cells) in many brain regions, for example, spinal cord, locus ceruleus, periaqueductal gray, thalamus, and caudate, cerebral, and cerebellar cortices (Bradley et al., 1976; Hill et al., 1976; Frederickson and Norris, 1976; Zieglgansberger and Fry, 1976; Nicoll et al., 1977; Young et al., 1977; Satoh et al., 1979; Zieglgansberger and Tulloch, 1979). However, the enkephalins appear to have a stimulatory role in the hippocampus, which might be due to their inhibition of an inhibitory interneuron (Nicoll et al., 1977; Mueller et al., 1979; Jensen et al., 1979; Zieglgansberger et al., 1979; Dunwiddie et al., 1980; Lee et al., 1980). Our findings, as well as those of Gall et al. (1981), indicate that the mossy fiber enkephalinergic system might be a more appropriate site to study the synaptic effects of the hippocampal enkephalins than field CA1, where most previous studies of hippocampal enkephalin pharmacology have focused.

As noted above, excitatory opioid effects in the central nervous system may occur indirectly, as a result of disinhibition (Nicoll et al., 1980). The latter investigators, studying the phenomenon of disinhibition in the turtle olfactory bulb, have shown that D-Ala-Met-enkephalinamide acts on the dendritic reciprocal synapses causing a dendrodendritic inhibition of mitral cells. Because olfactory centrifugal fibers make indirect contacts with mitral cells, perhaps via inhibitory interneurons (Halaz et al., 1978), Nicoll et al. (1980) have raised the possibility that some of these centrifugal fibers might contain enkephalin. In support of this suggestion, we have noted Leu-enkephalin-immunoreactive fibers in the intermediate olfactory tract, perhaps representing projections of immunoreactive perikarya in the anterior olfactory nucleus or other olfactory-related areas. These fibers appear to ascend in the bulb and distribute predominantly to the glomerular layer where they may interact with inhibitory periglomerular cells or possibly the dendrites of mitral cells. These findings are complemented by the 

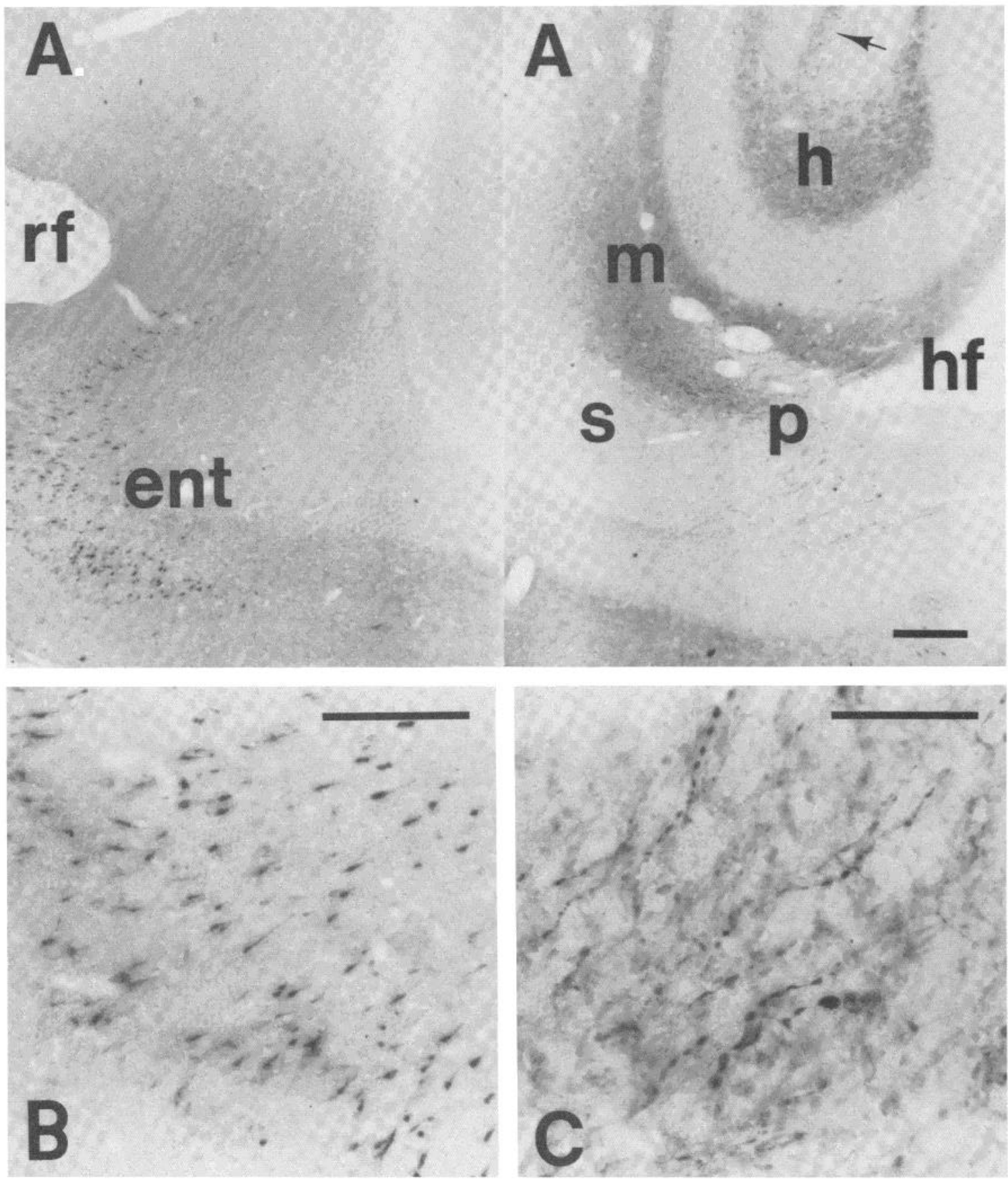

Figure 8. Entorhinal cortex-hippocampal formation. A shows a two-column wide photomontage of the entorhinal-hippocampal region in a frontal view. Leu-enkephalin-immunoreactive neurons in the entorhinal cortex (ent; magnified in $B$ ) seem to project via the perforant path $(p$; magnified in $C$ ) to the stratum moleculare $(m)$ of the dentate gyrus. Other areas of Leu-enkephalin immunoreactivity include the hilus $(h)$ of the dentate gyrus and mossy fiber projections (arrow) to the hippocampus. $h f$, hippocampal fissure; $r f$, rhinal fissure; $s$, subiculum. Bars: $A, 200 \mu \mathrm{m} ; B$ and $C, 50 \mu \mathrm{m}$.

demonstration of relatively dense opiate receptor binding in those bulb layers where such reciprocal dendrodendritic synapses occur (Nadi et al., 1980).

Some correspondence between enkephalin distribution and opiate receptor density has been noted previously in brains from different animals (Atweh and Kuhar, 1977; Simantov et al., 1977). The existence of several types of opiate receptors with different distributional patterns in the brain is well established (Lord et al., 1976; Chang and
Cuatrecasas, 1979; Goodman et al., 1980; Lewis et al., 1981a, b), but the anatomical relationships between different opiate receptor subtypes and the enkephalins (as well as other endogenous opioid peptides) have only begun to be explored. Although our knowledge of possible opioid peptide-receptor interactions has been enhanced by receptor autoradiographic studies (Pert et al., 1975; Atweh and Kuhar, 1977; Young and Kuhar, 1979; Goodman et al., 1980; Herkenham and Pert, 1980; Duka et al., 

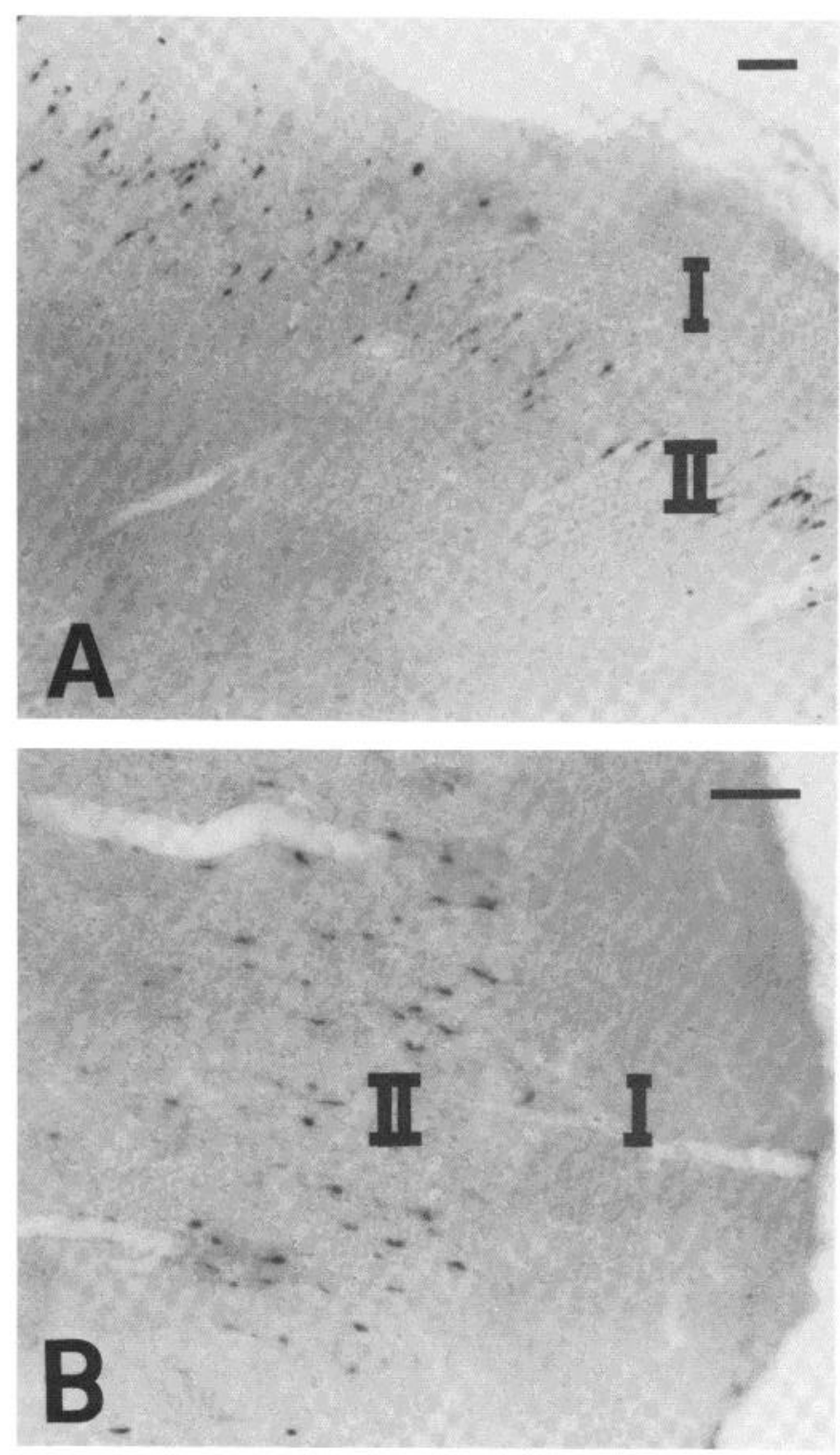

Figure 9. Cortical Leu-enkephalin-positive neurons shown in parasagittal sections. $A$ shows immunoreactive neurons in the frontal cortex. $B$ shows immunoreactive neurons in the parietal cortex. Note that the majority of these neurons are localized to layer II. Bars $=50 \mu \mathrm{m}$.

1981; Lewis et al., 1981b), anatomical demonstrations of opiate peptide-receptor subtype correlations require the application of methods for performing simultaneous immunocytochemistry and receptor autoradiography (Lewis et al., 1982).

\section{References}

Arnsten, A., S. D. Segal, H. Neville, and S. Hillyard (1981) Naloxone augments electrophysiological measures of selective attention in man. Soc. Neurosci. Abstr. 7: 659.

Atweh, S. F., and M. J. Kuhar (1977) Autoradiographic localization of opiate receptors in rat brain. II. The brain stem. Brain Res. 129: 1-12.

Belluzzi, J. D., and L. Stein (1977) Enkephalin may mediate euphoria and drive-reduction reward. Nature 266: 556-558.

Belluzzi, J. D., N. Grant, V. Garsky, D. Sarantakis, C. D. Wise, and L. Stein (1976) Analgesia induced in vivo by central administration of enkephalin in rat. Nature 260: 625-626.

Blackstad, T. W., K. Brink, J. Hem, and B. Jeune (1970) Distribution of hippocampal mossy fibers in the rat. An experimental study with silver impregnation methods. J. Comp. Neurol. 138: 443-450.

Bloom, F. E., E. Battenberg, J. Rossier, N. Ling, and R. Guillemin (1978) Neurons containing beta-endorphin in rat brain exist separately from those containing enkephalins: Immunocytochemical studies. Proc. Natl. Acad. Sci. U. S. A. 75: 1591-1595.

Bradley, P. B., I. Briggs, R. J. Gayton, and L. A. Lambert (1976) Effects of microiontophoretically applied methionine-enkephalin on single neurons in rat brainstem. Nature 261: 425426.

Chang, K. J., and P. Cuatrecasas (1979) Multiple opiate receptors. Enkephalins and morphine bind to receptors of different specificity. J. Biol. Chem. 254: 2610-2618.

Collier, T. J., J. S. Miller, G. Quirk, J. Travis, and A. Routtenberg (1981) Remembering rewards in the environment: Endogenous hippocampal opiates modulate reinforcementmemory associations. Soc. Neurosci. Abstr. 7: 359.

Comb, M., P. H. Seeburg, J. Adelman, L. Eiden, and E. Herbert (1982) Primary structure of the human Met- and Leu-enkephalin precursor and its mRNA. Nature 295: 663-666.

Cowan, A., J. C. Doxey, and G. Metcalf (1976) A comparison of pharmacological effects produced by leucine-enkephalin, methionine-enkephalin, morphine and ketocyclazacine. In Opiates and Endogenous Opiate Peptides, H. W. Kosterlitz, ed., pp. 95-102, Elsevier North-Holland Biochemical Press, Amsterdam.

Davis, G. C., M. S. Buchsbaum, and W. E. Bunney, Jr. (1980) Alterations of evoked potentials link research in attention dysfunction to peptide response symptoms of schizophrenia. In Neural Peptides and Neuronal Communication, E. Costa and M. Trabucci, eds., pp. 473-487, Raven Press, New York.

de Groot, J. (1959) The rat forebrain in stereotaxic coordinates. Verh. K. Ned. Akad. Wet. B. Natuurkd. 2: 1-40.

Duggan, A. W., J. G. Hall, and P. H. Headley (1976) Morphine, enkephalin and the substantia gelatinosa. Nature 264: 456458.

Duka, T., M. Wuster, P. Schubert, R. Stoiber, and A. Herz (1981) Selective localization of different types of opiate receptors in hippocampus as revealed by in vitro autoradiography. Brain Res. 205: 181-186.

Dunwiddie T., A. Muller, M. Palmer, J. Steward, and B. Hoffer (1980) Electrophysiological interactions of enkephalins with neuronal circuitry in the rat hippocampus. I. Effects on pyramidal cell activity. Brain Res. 184: 311-330.

Dupont, A., L. Cusan, F. Labrie, D. H. Coy, and C. H. Li (1977) Stimulation of prolactin release in the rat by intraventricular injection of $\beta$-endorphin and methionine-enkephalin. Biochem. Biophys. Res. Commun. 75: 76-82.

Elde, R., T. Hokfelt, O. Johansson, and L. Terenius (1976) Immunohistochemical studies using antibodies to leucineenkephalin: Initial observations on the nervous system of the rat. Neuroscience 1: 349-351.

Finley, J. C. W., J. L. Maderdrut, and P. Petrusz (1981) The immunocytochemical localization of enkephalin in the central nervous system of the rat. J Comp Neurol 198: 541-565.

Florez, J., and A. Mediavilla (1977) Respiratory and cardiovascular effects of met-enkephalin applied to the ventral surface of the brain stem. Brain Res. 138: 585-590.

Frederickson, R. C. A., and F. H. Norris (1976) Induced depression of single neurons in brain areas with opiate receptors, antagonism by naloxone. Science 194: 440-442.

Gall, C., N. Brecha, H. J. Karten, and K.-J. Chang (1981) Localization of enkephalin-like immunoreactivity to identified axonal and neuronal populations of the rat hippocampus. J. Comp. Neurol. 198: 335-350. 
Goldschmidt, R. B., and O. Steward (1982) Neurotoxic effects of colchicine: Differential susceptibility of CNS neuronal populations. Neuroscience 7: 695-714.

Goodman, R. R., S. H. Snyder, M. J. Kuhar, and W. S. Young (1980) Differentiation of delta and mu opiate receptor localizations by light microscopic autoradiography. Proc. Natl. Acad. Sci. U. S. A. 77: 6239-6243.

Gubler, U., P. Seeburg, B. J. Hoffman, L. P. Gage, and S. Udenfriend (1982) Molecular cloning establishes proenkephalin as precursor of enkephalin-containing peptides. $\mathrm{Na}$ ture 295: 206-208.

Halaz, N., A. Ljungdahl, and T. Kokfelt (1978) Transmitter histochemistry of the rat olfactory bulb. II. Fluorescence, histochemical, autoradiographic and electron microscopic localization of monoamines. Brain Res. 154: 253-271.

Herkenham, M., and C. B. Pert (1980) In vitro autoradiography of opiate receptors in rat brain suggests loci of opiatergic pathways. Proc. Natl. Acad. Sci. U. S. A. 77: 5532-5536.

Hill, R. G., C. M. Pepper, and J. F. Mitchell (1976) Depression of nociceptive and other neurons in the brain by iontophoretically applied met-enkephalin. Nature 262: 604-606.

Hjorth-Simonsen, A. (1972) Projections of the lateral part of the entorhinal area to the hippocampus and fascia dentata. J. Comp. Neurol. 145: 219-232.

Hokfelt, T., R. Elde, O. Johansson, L. Terenius, and L. Stein (1977a) The distribution of enkephalin-immunoreactive cell bodies in the rat central nervous system. Neurosci. Lett. 5: 25-31.

Hokfelt, T., A. Ljungdahl, L. Terenius, R. Elde, and C. Nilsson (1977b) Immunohistochemical analysis of peptide pathways possibly related to pain and analgesia: Enkephalin and substance P. Proc. Natl. Acad. Sci. U. S. A. 74: 3081-3085.

Hokfelt, T., L. Terenius, H. G. J. M. Kuypers, and O. Dann (1979) Evidence for enkephalin innunoreaclive neurons in the medulla oblongata projecting to the spinal cord. Neurosci. Lett. 14: 55-60.

Hollt, V., C. Grimm, I. Haarmann, B. R. Seizinger, and A. Herz (1981) Substantial amounts of immunoreactive BAM-12P and BAM-22P are present in bovine adrenal medulla but not in the brain. In Advances in Endogenous and Exogenous Opioids, H. Takagi and E. J. Simon, eds., pp. 152-154, Elsevier-North Holland Biomedical Press, Amsterdam.

Hughes, J., T. W. Smith, H. W. Kosterlitz, L. A. Fothergill, B. A. Morgan, and H. R. Morris (1975) Identification of two related pentapeptides from brain with potent opiate agonist activity. Nature 258: 577-579.

Jacobowitz, D. M., M. A. Silver, and W. G. Soden (1979) Mapping of leu-enkephalin containing axons and cell bodies of the rat forebrain. In Endorphins in Mental Health Research, E. Usdin, ed., pp. 62-74, Oxford University Press, New York.

Jensen, R., J. Martinez, R. Creager, J. Veliquitte, J. McGaugh, and G. Lynch (1979) Site of enkephalin action in the hippocampus. Soc. Neurosci. Abstr. 5: 530.

Kimura, S., R. V. Lewis, A. S. Stern, J. Rossier, S. Stein, and S. Udenfriend (1980) Probable precursors of Leu- and Metenkephalin in adrenal medulla: Peptides of 3-5 kilodaltons. Proc. Natl. Acad. Sci. U. S. A. 77: 1681-1685.

Kobayashi, R. M., M. Palkovits, R. J. Miller, K.-J. Chang, and P. Cautrecasas (1978) Brain enkephalin distribution is unaltered by hypophysectomy. Life Sci. 22: 527-530.

Larsson, L. I., S. Childers, and S. H. Snyder (1979) Methionine and leucine-enkephalin occur in separate neurons. Nature 22: 407-410.

Lee, H. R., T. Dunwiddie, and B. Hoffer (1980) Electrophysiological interactions of enkephalins with neuronal circuitry in the rat hippocampus. II. Effects on interncuron excitability. Brain Res. 184: 331-342.
Lewis, M. E., M. Mishkin, E. Bragin, R. Brown, C. B. Pert, and A. Pert (1981a) Opiate receptor gradients in monkey cerebral cortex: Correspondence with sensory processing hierarchies. Science 211: 1166-1169.

Lewis, M. E., A. Pert, C. B. Pert, and M. Herkenham (1981b) Laminar analysis of opiate receptor distribution in rat cerebral cortex. Soc. Neurosci. Abstr. 7: 502.

Lewis, M. E., H. Khachaturian, and S. J. Watson (1982) Visualization of opiate receptors and opioid peptides in sequential brain sections. Life Sci. 31: 1347-1350.

Leyben, L., C. Pinsky, F. S. La Bella, V. IIavlicek, and H. Rezek (1976) Intraventricular met-enkephalin causes unexpected lowering of pain threshold and narcotic withdrawal signs in rats. Nature 264: 458-459.

Lien, E. L., R. L. Fenichel, V. Garsky, D. Sarantakis, and N. H. Grant (1976) Enkephalin-stimulated prolactin release. Life Sci. 19: $837-840$.

Lord, J. A. H., A. A. Waterfield, J. Hughes, and H. W. Kosterlitz (1976) Multiple opiate receptors. In Opiates and Endogenous Opioid Peptides, H. W. Kosterlitz, ed., pp. 275-280, ElsevierNorth Holland Biomedical Press, Amsterdam.

Mains, R. E., B. A. Eipper, and N. Ling (1977) Common precursor to corticotropins and endorphins. Proc. Natl. Acad. Sci. U. S. A. 74: 3014-3018.

March, A. C., I. Parikh, and P. Cuatrecasas (1974) A simplified method for cyanogen bromide activation of agarose for affinity chromatography. Anal. Biochem. 60: 149-152.

May, P. B., J. C. Mittler, and N. H. Ertel (1979a) Enkephalins and pituitary hormone release: Modification of responsiveness to LH-RH. Horm. Res. 10: 57-63.

May, P. B., J. C. Mitler, A. Manougian, and N. Ertel (1979b) TSH release-inhibiting activity of leucine-enkephalin. Horm. Metab. Res. 11: 30-33.

Micevych, P., and R. Elde (1980) The relationship between enkephalinergic neurons and the vasopressin-oxytocin neuroendocrine system of the cat: An immunohistochemical study. J. Comp. Neurol. 190: 135-146.

Miller, R. J., K. -J. Chang, B. Coupex, and P. Cuatrecasas (1978) Radioimmunoassay and characterization of enkephalins in rat tissues. J. Biol. Chem. 253: 531-538.

Mizuno, K., N. Minamino, K. Kangawa, and H. Matsuo (1980) A new family of endogenous "big" met-enkephalins from bovine adrenal medulla: Purification and structure of docosa(BAM-22P) and eicosapeptide (BAM-20P) with very potent opiate activity. Biochem. Biophys. Res. Commun. 97: 12831290.

Mueller, A. L., T. V. Dunwiddie, M. R. Palmer, H. K. Lee, J. M. Steward, and B. Hoffer (1979) Enkephalins and hippocampal neuronal circuits. Proc. West. Pharmacol. Soc. 22: 471474.

Nadi, N. S., J. D. Hirsch, and I. L. Margolis (1980) Laminar distribution of putative neurotransmitter amino acids and ligand binding sites in the dog olfactory bulb. J. Neurochem. 34: 138-146.

Nakanishi, S., A. Inoue, T. Kita, M. Nakamura, A. C. Y. Chang, S. Cohen, and S. Numa (1979) Nucleotide sequence of cloned cDNA for bovine corticotropin-B-LPH precursor. Nalure 278: 423-427.

Nicoll, R. A., G. R. Siggins, N. Ling, F. E. Bloom, and R. Guillemin (1977) Neuronal actions of endorphins and enkephalins among brain regions: a comparative microiontophoretic study. Proc. Natl. Acad. Sci. U. S. A. 74: 2584-2588.

Nicoll, R. A., B. E. Alger, and C. E. Jahr (1980) Enkephalin blocks inhibitory pathways in the vertebrate CNS. Nature 287: 22-25.

Noda, M., Y. Furutani, H. Takahashi, M. Toyosato, T. Hirose, S. Inayama, S. Nakanishi, and S. Numa (1982) Cloning and sequence analysis of cDNA for bovine adrenal pre-proenke- 
phalin. Nature 295: 202-206.

Norstrom, A., H. A. Hansson, and J. Sjostrand (1971) Effects of colchicine on axonal transport and ultrastructure of the hypothalamo-neurohypophyseal system of the rat.Z. Zellforsch. 113: 271-293.

Pellegrino, L. J., A. S. Pellegrino, and A. J. Cushman (1979) A Stereotaxic Atlas of the Rat Brain, Ed. 2, Plenum Press, New York.

Pert, C. B., M. J. Kuhar, and S. Snyder (1975) Autoradiographic localization of the opiate receptor in brain. In The Opiate Narcotics: Neurochemical Mechanisms in Analgesia and Dependence, A. Goldstein, ed., pp. 97-101, Pergamon Press, New York.

Pickel, V. M., K. K. Sumal, S. C. Beckley, R. J. Miller, and D. J. Reis (1980) Immunocytochemical localization of enkephalin in the neostriatum of rat brain: A light and electron microscopic study. J. Comp. Neurol. 189: 721-740.

Roberts, J. L., and E. Herbert (1977) Characterization of a common precursor to corticotropin and beta-lipotropin: Identification of beta-lipotropin peptides and their arrangement relative to corticotropin in the precursor synthesized in a cellfree system. Proc. Natl. Acad. Sci. U. S. A. 74: 5300-5304.

Rossier, J., T. M. Vargo, S. Minick, N. Ling, F. E. Bloom, and R. Guillemin (1977) Regional dissociation of $\beta$-endorphin and enkephalin contents in rat brain and pituitary. Proc. Natl. Acad. Sci. U. S. A. 74: 5162-5165.

Rossier, J., E. Battenberg, Q. Pittman, A. Bavon, L. Koda, R. Miller, R. Guillemin, and F. Bloom (1979) Hypothalamic enkephalin neurons may regulate the neurohypophysis. Nature 227: 653-655.

Sar, M., W. E. Stumpf, R. J. Miller, K. -J. Chang, and P. Cuatrecasas (1978) Immunohistochemical localization of enkephalin in rat brain and spinal cord. J. Comp. Neurol. 182: 17-38.

Satoh, M., A. Akaike, and H. Takagi (1979) Excitation by morphine and enkephalin of single neurons of nucleus reticularis paragigantocellularis in the rat: A probable mechanism of analgesic action of opioids. Brain Res. 169: 406-410.

Simantov, R., M. J. Kuhar, G. R. Uhl, and S. H. Snyder (1977) Opioid peptide enkephalin: Immunohistochemical mapping in rat central nervous system. Proc. Nat. Acad. Sci. U. S. A. 74: $2167-2171$.

Snyder, S. H. (1980) Brain peptides as neurotransmitters. Science 209: $976-983$.

Steward, O. (1976) Topographic organization of the projections from the entorhinal area to the hippocampal formation of the rat. J. Comp. Neurol. 167: 285-314.

Swanson, L., J. Wyss, and W. M. Cowan (1978) An autoradi- ographic study of the organization of intrahippocampal association pathways in the rat. J. Comp. Neurol. 181: 681-716.

Uhl, G. R., M. J. Kuhar, and S. H. Snyder (1978) Enkephalincontaining pathway: Amygdaloid efferents in the stria terminalis. Brain Res. 149: 223-228.

Uhl, G. R., R. R. Goodman, M. J. Kuhar, S. R. Childers, and S. H. Snyder (1979) Immunocytochemical mapping of enkephalin containing cell bodies, fibers and nerve terminals in the brain stem of the rat. Brain Res. 116: 75-94.

Wamsley, J. K., W. S. Young, and M. J. Kuhar (1980) Immunocytochemical localization of enkephalin in rat forebrain. Brain Res. 190: 153-174.

Watson, S. J., and H. Akil (1981) Immunocytochemistry: Techniques, trials and tribulations. Neurosci. Commentaries 1: $10-15$.

Watson, S. J., H. Akil, S. Sullivan, and J. D. Barchas (1977a) Immunocytochemical localization of methionine-enkephalin: Preliminary observations. Life Sci. 25: 733-738.

Watson, S. J., J. D. Barchas, and C. H. Li (1977b) Betalipotropin: Localization of cells and axons in rat brain by immunocytochemistry. Proc. Natl. Acad. Sci. U. S. A. 74: 5155-5158.

Watson, S. J., H. Akil, C. W. Richard, and J. D. Barchas (1978) Evidence for two separate opiate peptide neuronal systems and the coexistence of beta-lipotropin, beta-endorphin, and ACTH immunoreactivities in the same hypothalamic neurons. Nature 275: 226-228.

Yang, H. -Y., J. S. Hong, and E. Costa (1977) Regional distribution of Leu and met-enkephalin in rat brain. Neuropharmacology 16: 303-307.

Young, W. S., and M. J. Kuhar (1979) A new method for receptor autoradiography: $\left[{ }^{3} \mathrm{H}\right] \mathrm{O}$ pioid receptors in rat brain. Brain Res. 179: 255-270.

Young, W. S., S. J. Bird, and M. J. Kuhar (1977) Iontophoresis of methionine-enkephalin in the locus coeruleus area. Brain Res. 129: 366-370.

Zieglgansberger, W., and J. P. Fry (1976) Actions of enkephalin on cortical and striatal neurons of naive and morphine tolerant/dependent rats. In Opiates and Endogenous Opioid Peptides, H. W. Kosterlitz, ed., pp. 231-238, Elsevier-North Holland Biomedical Press, Amsterdam.

Zieglgansberger, W., and I. 'Tulloch (1979) 'Ihe effects of methionine- and leucine-enkephalin on spinal neurons of the cat. Brain Res. 167: 53-64.

Zieglgansberger, W., E. French, G. Siggins, and F. E. Bloom (1979) Opioid peptides may excite hippocampal pyramidal neurons by inhibiting adjacent inhibitory interneurons. Science 205: 415-417. 